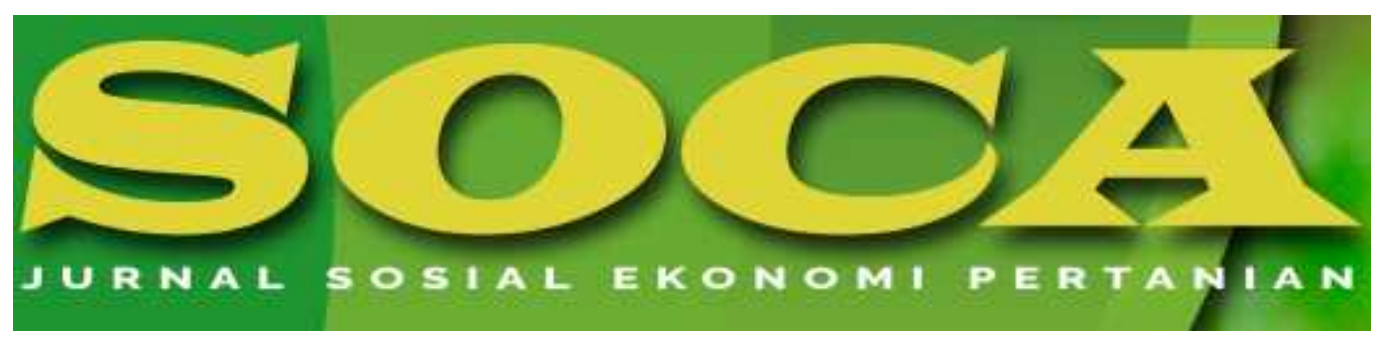

https://ojs.unud.ac.id/index.php/soca

\title{
KAJIAN KARAKTERISTIK PERILAKU KEWIRAUSAHAAN DAN KECENDERUNGAN BERMIGRASI PEDAGANG SAYURAN DI KOTA DENPASAR
}

\author{
Gede Mekse Korri Arisena dan Dwi Putra Darmawan \\ Program Studi Agribisnis Fakultas Pertanian Universitas Udayana \\ E-mail: korriarisena@unud.ac.id \\ HP: 081944864138
}

\section{Kata Kunci: \\ kewirausahaan, sayuran dan inovasi waktu}

\begin{abstract}
Abstrak
Pedagang sayuran dengan waktu operasional sore hingga malam hari, tentunya memiliki perilaku tertentu dalam berwirausaha dan mengambil keputusan untuk bermigrasi dari daerah asal yang menarik untuk dikaji. Tujuan penelitian ini adalah menganalisis karakteristik, perilaku wirausaha dan kecenderungan bermigrasi pedagang Sayuran di Desa Ubung Kaja. Penelitian ini dilaksanakan di Desa Ubung Kaja. Lokasi penelitian dipilih secara sengaja (purposive sampling) dengan pertimbangan Desa Ubung Kaja merupakan daerah yang sebagian besar wilayahnya merupakan lokasi perumahan/pemukiman penduduk di Kecamatan Denpasar Utara dan Kecamatan Denpasar Utara adalah daerah padat pemukiman di Kota Denpasar. Desain penelitian yang dilakukan adalah metode survey. Pengumpulan data digunakan dengan observasi dan wawancara langsung. Data yang diperoleh dianalisis dengan analisis deskriptif, regresi logistik dan SEM-PLS. Pedagang sayuran bermigrasi dari daerah asal ke Desa Ubung Kaja (daerah rantauan) dipengaruhi oleh umur pendapatan, status perkawinan, kepemilikan asset dan pekerjaan di daerah asal. Hasil analisis diperoleh perilaku kewirausahaan pedagang termasuk dalam kategori baik.
\end{abstract}

\section{STUDY CHARACTERISTIC ENTREPRENEUR BEHAVIOR AND TREND TO MIGRATE VEGETABLE SELLER IN DENPASAR CITY}

\section{Keywords: \\ entrepreneurship,}

\author{
Abstrak \\ Vegetable traders with operational time in the afternoon \\ until evening, of course, have certain behaviors in
}


vegetables and time innovation
Entrepreneurship and make the decision to migrate from the area of origin that is interesting to study. The purpose of this study was to analyze the characteristics, entrepreneurial behavior and trends of migrating Vegetable traders in Ubung Kaja Village. This research was conducted in the village of Ubung Kaja. The research location was chosen intentionally (purposive sampling) considering that Ubung Kaja Village is an area where most of the area is a residential / residential location in North Denpasar District and North Denpasar District is a densely populated area in Denpasar City. The research design carried out was a survey method. Data collection is used by direct observation and interviews. The data obtained were analyzed by descriptive analysis, logistic regression and SEM-PLS. Vegetable traders migrate from the area of origin to the village of Ubung Kaja (overseas areas) influenced by age of income, marital status, asset ownership and employment in the area of origin. The analysis results obtained entrepreneurial entrepreneurial behavior included in both categories.

How to Cite (APA 6th Style):

Arisena, G. M. K., \& Darmawan, D. P. (2020). Kajian Karakteristik Perilaku Kewirausahaan dan Kecenderungan Bermigrasi Pedagang Sayuran di Kota Denpasar. SOCA: Jurnal Sosial Ekonomi Pertanian, 14(1), 169-179. https://doi.org/10.24843/SOCA.2020.v14.i01.p14

\section{PENDAHULUAN}

Desa Ubung Kaja merupakan daerah yang sebagian besar wilayahnya merupakan lokasi perumahan/pemukiman penduduk di Kecamatan Denpasar Utara. Mengingat Kecamatan Denpasar Utara adalah daerah padat pemukiman di Kota Denpasar, posisi strategis ini berdampat terhadap pesatnya pertumbuhan ekonomi sektor informal di Kecamatan Denpasar Utara. Pesatnya Perkembangan Sektor Informal di Denpasar Utara, diwarnai dengan munculnya kaum pendatang dari luar Kota Denpasar, yang mencoba mencari nafkah dengan bekerja di sector informal. Posisi strategis Kecamatan Denpasar Utara juga berdampak terhadap munculnya pedagang-pedagang sayuran dengan inovasi baru, yang tidak lagi beroperasional di pagi hari melainkan telah bergeser waktu operasional ke sore hingga malam hari. Usaha para pedagang sayuran merupakan salah satu bentuk dari sector ekonomi informal.

Inovasi yang dilakukan pedagang sayuran dengan memilih waktu operasional sore hingga malam hari, secara tidak langsung sudah meniru gaya manajemen ritel modern. Ritel moderen seperti pasar swalayan umumnya menunggu konsumen untuk berbelanja kebutuhan sayuran dan memiliki sumber dana yang kuat dalam melakukan pemasaran sayuran. Hal ini bertolak belakang dengan pemasaran sayuran secara tradisional yang sebelumnya banyak dilakukan terutama menyangkut jam operasional yaitu di pagi hari. Teknologi yang digunakan juga masih tradisional, kurang memperhatikan kualitas sumberdaya manusia dan terbatasnya modal yang dimiliki. 
Hadiyati (2012) mengungkapkan inovasi dan kreativitas berpengaruh signifikan secara silmutan terhadap pemasaran pada usaha kecil Keramik Dinoyo Malang. Lebih lanjut Mustikowati and Tysari (2014) inovasi berpengaruh secara langsung dan positif terhadap kinerja perusahaan, semakin kuat inovasi, orientasi kewirausahaan dan strategi bisnis yang dimiliki oleh perusahaan maka akan meningkatkan kinerja perusahaan.

Perilaku pedagang sayuran dalam berwirausaha menatik untuk dikaji, karena motivasi berwirausaha sangat besar. Hal ini terlihat dari pengalokasian waktu kerja, dimana waktu yang seharusnya mereka gunakan untuk beristirahat mereka pergunakan untuk berusaha/bekerja. Sebagian besar pedagang sayuran memulai usaha/berjualan jam empat sore hingga berakhir jam 10 malam. Apabila dilihat dari sisi usia sebagian besar pedagang berusia belasan sampai tiga puluhan, hal ini sejalan dengan apa yang kita ketahui bersama fisik yang muda membuat pedagang semakin lincah dan mampu melahirkan motivasi diri yang besar.

Gemina, Silaningsih, and Yuningsih (2016) mengungkapkan motivasi usaha berpengaruh terhadap kemampuan usaha, semakin tinggi motivasi usaha maka akan semakin tinggi pula kemampuan usaha. Lebih lanjut Purnama and Suyanto (2010) mengungkapkan motivasi usaha dengan indikator motif, harapan dan insentif, ketiga indikator tersebut secara bersama-sama mampu menjelaskan variabel motivasi usaha. Dari ketiga indikator tersebut, harapan paling besar dalam bembentuk motivasi usaha. Hasil penelitian Aidha (2016) menambahkan Motivasi berwirausaha mahasiswa FKM UIN-SU tinggi, hal ini terlihat dari indikator pada dimensi Ambition for freedom, Self Realisation, dan Pushing Factors.

Fenomena kaum urban, yang mencoba mengadu nasib di Kota Denpasar menarik untuk dikaji, ditambah lagi karakteristik usaha dan individu diduga sangat kuat mempengaruhi perilaku wirausaha pedagang sayuran dengan jam operasional sore hingga malam hari. Disisi lain perilaku wirausaha diduga juga dapat meningkatkan pendapatan dan kesejahteraan tidak hanya pedagang itu sendiri tetapi keluarga pedagang sayuran juga dapat terkena imbasnya. Oleh karena itu menarik untuk dilaksanakan penelitian tentang perilaku wirausaha dan kecenderungan bermigrasi pedagang Sayuran di Kota Denpasar.

\section{METODA PENELITIAN}

Penelitian ini dilaksanakan di Desa Ubung Kaja, lokasi dipilih secara sengaja (purposive sampling) dengan alasan Desa Ubung Kaja merupakan daerah yang sebagian besar wilayahnya merupakan lokasi perumahan/pemukiman penduduk di Kecamatan Denpasar Utara dan Kecamatan Denpasar Utara adalah daerah padat pemukiman di Kota Denpasar. Penelitian dilaksanakan pada bulan Maret September 2019 Penelitian dilaksanakan pada bulan Januari - Agustus 2019. Populasi dalam penelitian ini adalah pedagang sayuran dengan jam operasional sore hingga malam hari di Desa Ubung Kaja. Sampel diperoleh dengan menggunakan metode sensus (sampel adalah semua anggota populasi).

Desain penelitian yang dilakukan adalah metode survey. Metode survey adalah prosedur dan teknik pengumpulan data untuk memperoleh fakta-fakta dari gejala-gejala yang ada dan mencari keterangan secara faktual baik tentang social dan ekonomi pedagang sayuran dengan jam operasional sore hingga malam hari di Desa Ubung Kaja. Teknik pengumpulan data yang dilakukan adalah wawancara 
langsung, dan observasi. Ada tiga jenis analisis yang akan digunakan dalam penelitian ini, yaitu analisis Statistik Deskriptif, regresi logistik dan SEM-PLS.

\section{HASIL DAN PEMBAHASAN}

\section{Faktor-Faktor Yang Menyebabkan Pedagang Sayuran Bermigrasi Dari Daerah Asal Ke Desa Ubung Kaja}

Penelitian ini menggunakan beberapa hipotesis faktor yang menyebabkan pedagang sayuran bermigrasi dari daerah asal ke Desa Ubung Kaja (daerah rantauan). Keinginan pedagang untuk menetap di daerah Denpasar (rantauan) dipengaruhi oleh pendapatan, umur, pendidikan, status perkawinan, kepemilikan aset di daerah asal, pekerjaan di daerah asal. Hasil analisis tujuan satu pendidikan tidak memiliki pengaruh signifikan terhadap keinginan pedagang untuk menetap di Desa Ubung Kaja. Sedangkan kelima variable lainnya yaitu UMUR, PENDAPATAN, SP, KA dan PA memiliki pengaruh signifikan terhadap keinginan pedagang untuk menetap di Desa Ubung Kaja.

Keinginan menetap pedagang sayuran disebabkan oleh kondisi lingkungan sosial dan ekonomi para pedagang yang berbeda-beda. Disaat umur mereka mulai bertambah pedagang akan semakin dewasa memikirkan apa yang harus di kerjakan untuk menopang kebutuhan ekonomi yang semakin bertambah. Pekerjaan di daerah asal yang dianggap kurang layak secara pendapatan yang di peroleh akan memotivasi mereka untuk lebih kreatif dan inovatif mencari sumber-sumber pendapan baru yang bisa mendatangkan pendapatan yang lebih layak. Pedagang yang notabene sebagai perantau ingin bekerja di Desa Ubung Kaja memperoleh pendapatan yang lebih tunggi dibandingkan dengan pekerjaan yang sebelumnya mereka tekuni di daerah asal. Perbedaan pendapatan yang diperoleh memicu pedagang untuk lebih lama untuk menetap di Desa Ubung Kaja.

Tabel 1. Output Koefisien Regresi Logistik

\begin{tabular}{lccc}
\hline \multicolumn{1}{c}{ Variabel } & Koefisien & Wald-ratio & Sig. (p-value) \\
\hline UMUR & -.639 & 13.883 & $.040^{*}$ \\
PENDIDIKAN & -.120 & .408 & .457 \\
PENDAPATAN & 2.242 & 6.648 & $.027^{* *}$ \\
SP (status pernikahan) & -.877 & 4.950 & $.034^{* *}$ \\
KA (kepemilikan asset di daerah asal) & -.330 & 5.409 & $.017^{* *}$ \\
PA (pekerjaan di daerah asal) & -.012 & 17.105 & $.087^{*}$ \\
Constant & 7.698 & 26.678 & $.000^{*}$ \\
\hline
\end{tabular}

Sumber: Diolah dari data primer 2019

Keterangan:

**:signifikansi pada taraf alpha $5 \%$.

* :signifikansi pada taraf alpha $1 \%$

Hasil analisis menjelaskan bahwa UMUR, PENDIDIKAN, SP, KA dan PA memiliki hubungan negative terhadap niat pedagang untuk menetap di Desa Ubung Kaja. Sebagian besar pedagang memiliki aset di daerah asalnya (seperti rumah atau lahan pertanian) sehingga masih ada harapan di hari tua mereka masih ada tempat yang dituju. Hasil analisis ini dapat dideskripsikan lebih dalam para pedagang hanya ingin berjualan di derah rantauan (Desa Ubung Kaja) dengan tujuan untuk 
meningkatkan taraf hidup dan kesehjateraan keluarganya, mereka memiliki keinginan setelah tua (lanjut usia) akan kembali kedaerah asal mereka untuk menikmati hari tuanya (masa pensiun).

\section{Karakteristik Individu dan Usaha}

Karakteristik pedagang sayuran di Desa Ubung Kaja terdiri dari dua yaitu karakteristik usaha dan wirausaha. Dalam penelitian ini karakteristik usaha pedagang sayuran dilihat dari: status kepemilikan usaha, pengalaman menjalankan usaha, asal produk sayuran, jam kerja dan penerimaan usaha. Selain karakteristik individu dalam penelitian ini juga dianalisis karakteristik wirausaha pedagang yang dilihat dari: kejujuran, ramah dan berani terhadap risiko. Hasil tabulasi karakteristik wirausaha pedagang secara lebih lengkap dapat dilihat pada Tabel 2 .

Tabel 2. Karakteristik wirausaha pedagang sayuran di Desa Ubung Kaja Tahun 2019

\begin{tabular}{clcc}
\hline No & \multicolumn{1}{c}{ Karakteristik Wirausaha } & Rataan Skor & Kategori \\
\hline 1 & Berani terhadap risiko & 77 & Baik \\
2 & Ramah & 88 & Sangat Baik \\
3 & Kejujuran & 82 & Sangat Baik \\
\hline
\end{tabular}

Sumber: Diolah dari data primer 2019

Pedagang sayuran dalam menghadapi risiko memiliki kemampuan yang berbeda-beda, kemampuan dalam menghadapi resiko akan terlihat dari usahanya apakah berjalan baik atau tidak. Usaha sayuran yang digeluti oleh pedagang pasti memiliki resiko dalam menjalanlankannya, baik resiko yang bersifat besar maupun kecil. Mau tidak mau pedagang harus dituntut untuk mengambil pilihan dan berani menghadapi resiko usaha yang ada didalamnya. Berdasarkan hasil penelitian diperoleh hasil pedagang sayuran di Desa Ubung Kaja dihadapkan pada berbagai resiko dalam menjalankan usaha, mereka harus menghadapi segala resiko yang akan dating. Dalam Tabel 2, terlihat rataan skor berani menghadapi resiko memiliki nilai sebesar 77 yang termasuk dalam kategori baik.

Lebih lanjut dari berdasarkan data yang ada pada Tabel 2, menunjukkan rataan skor ramah memiliki nilai sebesar 88 yang termasuk dalam kategori sangat baik dan rataan skor pada kejujuran memiliki nilai sebesar 82 yang termasuk dalam kategori sangat baik. Dalam menjalankan usaha pedagang harus memiliki prilaku yang ramah, ramah dalam hal ini adalah sikap sopan dan selalu memberi senyuman kepada konsumen yang sedadang berkunjung. Dari hasil wawancara di lapangan, para pedagang juga meyakini dalam berusaha harus disertai kejujuran. Perilaku kecurangan dalam berusaha akan membawa akibat yang buruk bagi pedagang, sehingga berdampak terhadap kehilangan kepercayaan konsumen yang pada akhirnya akan menurunkan keuntungan usaha yang diperoleh.

\section{Status Kepemilikan Usaha}

Sebagian besar usaha yang dijalankan oleh pedagang sayuran di Desa Ubung Kaja adalah usaha sendiri sebanyak 15 orang $75 \%$ dan sisanya milik keluarga sebanyak 5 orang 25\%. Kepemilikan usaha milik sendiri/pribadi memiliki arti semua modal dari sewa tempat, peralatan dan penyedian produk. Usaha milik sendiri menyebabkan pedagang tidak tergantung dengan orang lain, dari sisi 
ekonomi usaha milik sendiri juga mampu membuka lapangan pekerjaan, dengan demikian semakin banyak usaha milik sendiri maka akan menciptakan lapangan pekerjaan. Dari hasil pengamatan sebagian besar pedagang dalam melaksanakan proses operasional hanya berkerja sendiri tanpa dibantu dengan karyawan. Sebagian besar pedagang beralasan mereka tidak dibantu karyawan karena, bagi mereka pekerjanya berjualan dianggap tidak terlalu sulit dan juga dapat menghemat biaya produksi yang berasal dari biaya tenaga kerja. Distribusi pedagang berdasarkan status kepemilikan usaha bisa dilihat pada Tabel 3.

Tabel 3. Distribusi Status Kepemilikan Usaha Tahun 2019

\begin{tabular}{clll}
\hline No & Status Kepemilikan Usaha & Frekuensi (Orang) & Persentase (\%) \\
\hline 1 & Sendiri & 15 & $75 \%$ \\
2 & Keluarga & 5 & $25 \%$ \\
& Jumlah & 20 & $100 \%$ \\
\hline
\end{tabular}

Sumber: Diolah dari data primer 2019

\section{Pengalaman Menjalankan Usaha}

Pengalaman berusaha pedagang sayuran di Desa Ubung Kaja berdasarkan pengalaman berusaha, paling lama adalah 36 bulan (tiga tahun) hal itu dikarenakan inovesi pedagang sayuran yang mulai berjualan pada malam hari mulai menjabur di era tahun 2016. Sebagian besar pedagang memiliki pengalaman berdagang di bawah 12 bulan. Fenomena ini menggambarkan bahwa masih banyak pedagang baru yang melihat peluang untuk memulai usaha berjualan sayuran. Distribusi pedagang berdasarkan kelompok pengalaman menjalankan usaha bisa dilihat pada Tabel 4.

Tabel 4. Distribusi Pengalaman Menjalankan Usaha Tahun 2019

\begin{tabular}{cccc}
\hline No & $\begin{array}{c}\text { Pengalaman } \begin{array}{c}\text { Menjalankan Usaha } \\
\text { (Bulan) }\end{array} \\
\text { Frekuensi (Orang) }\end{array}$ & Persentase (\%) \\
\hline 1 & $<12$ & 11 & $55 \%$ \\
2 & $12-36$ & 9 & $45 \%$ \\
3 & $>36$ & 0 & 0 \\
\hline & Jumlah & 20 & $100 \%$ \\
\hline
\end{tabular}

Sumber: Diolah dari data primer 2019

\section{Jam Kerja}

Proses waktu yang diperlukan sari persiapan membukan tempat berjualan, menata produk sampai proses penjualan sayuran. Jam kerja berdagang yang umum dilakukan oleh pedagang adalah mulai pukul $16.00-21.00$ dan $18.00-21.00$. Jam kerja yang paling banyak yaitu selama 5 jam/hari dilakukan oleh 16 orang pedagang $80 \%$, sedangkan yang paling jam kerja yang paling singkat antara 3 jam/hari dilakukan oleh 4 orang pedagang $20 \%$ persen.

Hasil penelitian menunjukkan mayoritas pedagang sayuran di Desa Ubung Kaja bekerja di bawah standar normal yaitu delapan jam per hari. Kondisi ini ini merupakan inovasi yang dilakukan oleh pedagang, dimana selama ini penjualan sayuran identic dilakukan pada pagi hari, kini pedagang berdagang pada sore hari disesuaikan dengan pembeli yang sebagian besar "malas" untuk berbelanja di pagi hari, mereka menyetok sayuran untuk dimasak keesokan harinya atau pembeli yang 
menginginkan sayuran segar untuk dimasak pada malam hari (makan malam). Distribusi jam kerja berdagang per hari secara lebih rinci bisa dilihat pada Tabel 5 .

Tabel 5. Distribusi Berdasarkan Jam kerja Tahun 2019

\begin{tabular}{cccc}
\hline No & Jam Kerja (Jam) & Frekuensi (Orang) & Persentase (\%) \\
\hline 1 & $<3$ & 4 & $20 \%$ \\
2 & $>3$ & 16 & $80 \%$ \\
& Jumlah & 20 & $100 \%$ \\
\hline
\end{tabular}

Sumber: Diolah dari data primer 2019

\section{Asal Produk Sayuran}

Kebutuhan sayuran untuk masing-masing pedagang beranekaragam. Satu pedagang memiliki perkebunan di daerah bedugul, dan sekaligus memasarkan produk hasil kebunnya. Tiga orang pedagang mencari langsung produk sayuran yang akan di pasarkan langsung ke pasar induk. Sebagian besar pedagang menggunakan jasa suplayer untuk memenuhi kebutuhan produknya karena di anggap paling efisien. Distribusi asal produk sayuran asal produk sayuran dapat dilihat pada Tabel 6.

Tabel 6. Distribusi Pedagang Berdasarkan Asal Produk Sayuran Tahun 2019

\begin{tabular}{clcc}
\hline No & \multicolumn{1}{c}{ Asal Produk Sayuran } & Frekuensi (Orang) & Persentase (\%) \\
\hline 1 & Suplayer & 16 & $80 \%$ \\
2 & Mencari Ke Pasar Induk & 3 & $15 \%$ \\
3 & Kebun Sendiri & 1 & $5 \%$ \\
& Jumlah & 20 & $100 \%$ \\
\hline
\end{tabular}

Sumber: Diolah dari data primer 2019

\section{Penerimaan Usaha}

Hasil penelitian diperoleh Rp 500.000 sebanyak 11 orang, penerimaan diantara Rp 500.000 - Rp 1.500 .000 berjumlah 8 orang dan penerimaan diatas $\mathrm{Rp}$ 1.500.000 berjumlah 1 orang. Terjadinya perbedaan penerimaan usaha yang di peroleh antar pedagang yang berusaha di Desa Ubung Kaja disebabkan oleh berbagai factor, antara lain perbedaan kelengkapan produk sayuran yang di pasarkan, selain itu juga disebabkan oleh factor lokasi berdagang, semakin setrategis lokasi berdagang semakin besar juga peluang penerimaan yang dihasilkan. Besarnya jumlah rupiah sebagai penerimaan usaha yang diperoleh oleh pedagang diharapkan mampu menjadi motivasi baru bagi para pedagang. Besarnya penerimaan usaha diharapkan juga mampu menjadi motivasi bagi seorang wirausahawan untuk lebih fokus dalam menekuni usaha. Secara lebih lengkap penerimaan usaha pedagang sayuran di Desa Ubung kaja dirinci pada Tabel 7.

Tabel 7. Distribusi Penerimaan Usaha Tahun 2019

\begin{tabular}{cccc}
\hline No & Penerimaan Usaha (Rp/Hari) & Frekuensi (Orang) & Persentase $(\%)$ \\
\hline 1 & $<500.000$ & 11 & $55 \%$ \\
2 & $500.000-1.500 .000$ & 8 & $40 \%$ \\
3 & $>1.500 .000$ & 1 & $5 \%$ \\
& Jumlah & 20 & $100 \%$ \\
\hline
\end{tabular}

Sumber: Diolah dari data primer 2019 


\section{Perilaku wirausaha pedagang sayuran}

Hasil penelitian menunjukkan perilaku kewirausahaan pedagang memiliki nilai 219 yaitu berada dalam kategori baik, nilai tersebut berasal dari pengetahuan yang memiliki nilai rataan skor sebesar 84, keterampilan memiliki nilai sebesar 57 dan sikap meniliki nilai sebesar 78 . Hasil analisis menunjukkan pedagang memiliki perilaku yang baik dalam berusaha. Perilaku kewirausahaan yang tergolong dalam katagori baik terlahir karena dorongan rasa tanggung jawab yang tumbuh dari diri pedagang untuk memperbaiki kesehjateraan mereka. Disamping itu usaha penjualan sayuran adalah mata pencaharian utama mereka. Pedagang dituntut untuk melakukan aktivitas mengelola usaha gar mencapai keberhasilan dengan menguasai manajemen bisnis produk sayuran. Perilaku Wirausaha Pedagang Sayuran di Desa Ubung Kaja secara lebih lengkap dapat dilihat pada tabel 8.

Tabel 8. Perilaku Wirausaha Pedagang Sayuran di Desa Ubung Kaja tahun 2019.

\begin{tabular}{clcc}
\hline No & \multicolumn{1}{c}{ Keterangan } & Rataan Skor & Katagori \\
\hline 1 & Pengetahuan Wirausaha & 84 & Sangat Baik \\
2 & Sikap Wirausaha & 78 & Baik \\
3 & Keterampilan Wirausaha & 57 & Cukup Baik \\
\hline & Perilaku Wirausaha & 219 & Baik \\
\hline
\end{tabular}

Sumber: Diolah dari data primer 2019

Pengetahuan kewirausahaan yang dimiliki pedagang sayuran akan menggambarkan sampai sejauh mana kemampuan berfikir pedagang dalam menjalankan dan mengelola usahanya menggunakan ilmu kewirausahaan yang mereka miliki. Ilmu kewirausahaan tersebut bisa diperoleh dari pelajaran yang diberikan oleh orang lain, pengalaman berwirausaha, jaringan social dan dapat juga diperoleh dari buku maupun berita di media massa. Berdasarkan hasil penelitian, menunjukkan nilai rataan hitung skor sikap kewirausahaan pedagang sebesar 78 yang termasuk dalam kategori baik.

Hasil penelitian Trisnawati (2014) menunjukkan secara simultan terdapat pengaruh pengetahuan kewirausahaan dan dukungan sosial keluarga pada minat berwirausaha. Lebih lanjut Aprilianty (2013) Pengetahuan kewirausahaan berpengaruh positif dan signifikan terhadap minat berwirausaha siswa SMK Rumpun Pertanian di Daerah Istimewa Yogyakarta. Josia Sanchaya Hendrawan (2017) menambahkan variabel utama dalam membangun minat untuk berwirausaha mahasiswa adalah pengetahuan kewirausahaan yang dimiliki mahasiswa tersebut.

Keterampilan pedagang sayuran dalam menjalankan aktifitas usahanya, seperti: rencana pengembangan usaha, pembukuan keuangan dan membuat strategi pemasaran. Hal ini menunjukkan keterampilan pedagang sayuran rendah dalam mengatur dan mengelola usahanya, seperti penerapan manajemen keuangan sederhana dalam bentuk pembukuan keuangan yang jarang bahkan tidak pernah dilaksanakan oleh pedagang. Hasil analisis menunjukkan keterampilan berwirausaha pedagang sayuran sebesar 57 , tergolong cukup baik. 
Hubungan Antara Karakteristik Pedagang Dengan Perilaku Wirausaha Pedagang Sayuran Dengan Jam Operasional Sore Hingga Malam Hari Di Desa Ubung Kaja

Analisis Structural Equation Modeling-Partial Least Square (SEM-PLS). Uji convergent validity indikator refleksif dapat dilihat dari nilai loading factor untuk setiap konstruk, dimana nilai loading factor yang direkomendasikan harus lebih besar dari 0,7 untuk penelitian yang bersifat confirmatory. Indikator dianggap valid jika memiliki nilai outer loading $>0,7$ dan nilai $t$-statistic $>2,36$. Nilai outer loading dan $t$-statistik masing- masing indikator pada penelitian ini dapat dilihat pada Tabel 9. Pengujian outer model pada Tabel 9, dapat dilihat semua indikator memiliki nilai outer loading $>0,7$ dan $t$-statistik $>2,36$, sehingga sudah memenuhi kriteria uji convergent validity.

Tabel 10. Nilai Outer Loading dan T-Statistik

\begin{tabular}{cllcc}
\hline Indikator & Parameter & $\begin{array}{c}\text { Nilai Outer } \\
\text { Loading }\end{array}$ & T-Statistic \\
\hline Karakteristik Individu & a. & KI 1 & 0,865 & 13,212 \\
(KI) & b. KI 2 & 0,837 & 13,574 \\
Karakteristik & c. KI 3 & 0,873 & 7,435 \\
Wirausaha (KU) & a. KU 1 & 0,922 & 29,789 \\
Perilaku & b. KU 2 & $-0,814$ & 6,909 \\
Kewirausahaan (PE) & c. KU 3 & 0,954 & 58,855 \\
& a. PE & 0,855 & 23,953 \\
& b. PE 2 & 0,953 & 59,698 \\
\hline
\end{tabular}

Sumber: Diolah dari data primer 2019

Pada pengujian validitas discriminant dengan indikator refleksif adalah dengan melihat nilai cross loading untuk setiap variabel $(>0,70)$. Pengujian discriminant validity yang di peroleh dalam penelitian ini dapat dilihat pada Tabel 10 .

Tabel 11. Discriminant Validity

\begin{tabular}{clcl}
\hline No & \multicolumn{1}{c}{ Variabel } & AVE & $\sqrt{A}$ \\
\hline 1 & Karakteristik Individu & O,737 & 0,858 \\
2 & Karakteristik Wirausaha & 0,808 & 0,899 \\
3 & Perilaku Kewirausahaan & 0,852 & 0,923 \\
\hline \multicolumn{2}{l}{ Sumber: Diolah dari data primer 2019 } &
\end{tabular}

Berdasarkan Tabel 11 dapat dilihat bahwa ketiga variabel Karakteristik Individu, Karakteristik Wirausaha dan Perilaku Kewirausahaan memiliki nilai Cross Loading berada diatas 0,70 dan nilai akar AVE lebih tinggi dari koefisien korelasi variabel laten. Hal ini berarti pengujian discriminant validity dengan membandingkan akar kuadrat AVE untuk setiap konstruk dengan nilai korelasi antar konstruk dalam model menunjukkan bahwa seluruh variabel yang digunakan dalam penelitian ini atas dikatakan baik/valid. 


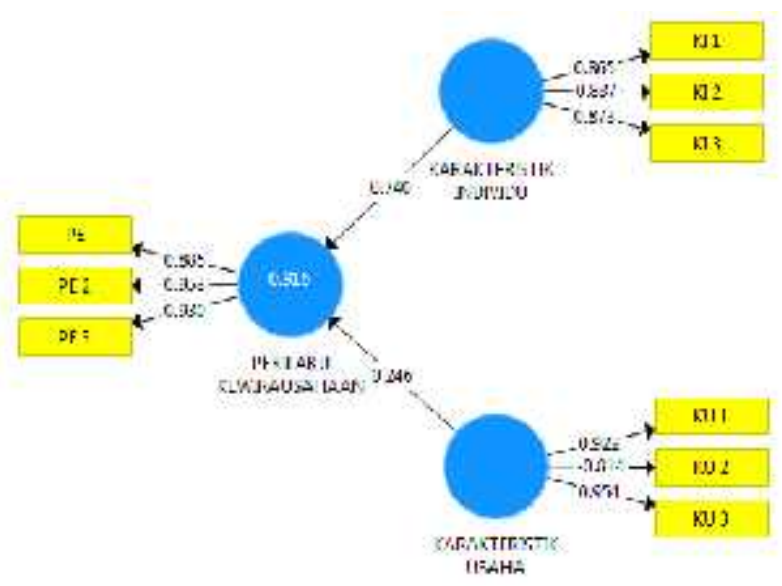

Gambar 1. Model Struktural

Sumber: Hasil analisis data primer, 2019

Dalam gambar 1, dapat dilihat bahwa karakteristik individu dan usaha berpengaruh positif terhadap perilaku kewirausahaan pedagang sayuran. Dari hasil penelitian karakteristik individu memiliki pengaruh yang lebih besar dalam membentuk perikalu kewirausahaan pedagang dibandingkan dengan karakteristik usaha.

\section{KESIMPULAN DAN SARAN}

\section{Simpulan}

Pedagang sayuran bermigrasi dari daerah asal ke Desa Ubung Kaja (daerah rantauan) dipengaruhi oleh umur pendapatan, status perkawinan, kepemilikan asset dan pekerjaan di daerah asal. Hasil analisis diperoleh perilaku kewirausahaan pedagang termasuk dalam kategori baik.

\section{Saran}

Diperlukan adanya pelatihan literasi keuangan bagi pedagang dengan harapan pada akhirnya pedagang mampu meningkatkan kompetensi kewirausahaan mereka.

\section{UCAPAN TERIMA KASIH}

Penulis mengucapkan terima kasih kepada Ketua Lembaga Penelitian dan Pengabdian kepada Masyarakat (LPPM) dan Dekan Fakultas Pertanian Universitas Udayana atas bantuan dana dalam penelitian dan penulisan artikel ini melalui anggaran PNBP UNUD (skim Penelitian Unggulan Program Studi).

\section{DAFTAR PUSTAKA}

Aidha, Zuhrina. 2016. "Pengaruh Motivasi Terhadap Minat Berwirausaha Mahasiswa Fakultas Kesehatan Masyarakat Universitas Islam Negeri Sumatera Utara." Jurnal Jumantik 1 (1): 42-59.

Aprilianty, Eka. 2013. "Pengaruh Kepribadian Wirausaha, Pengetahuan Kewirausahaan, Dan Lingkungan Terhadap Minat Berwirausaha Siswa SMK." Jurnal Pendidikan Vokasi https://doi.org/10.21831/jpv.v2i3.1039. 
Fauzah R. 2013. Perilaku Kewirausahaan Pedagang Warung Tenda Pecel Lele Kerukunan Keluarga Besar Siman Jaya (KKBSJ) di Jakarta. [skripsi]. Bogor (ID): Institut Pertanian Bogor.

Gemina, Dwi, Endang Silaningsih, and Erni Yuningsih. 2016. "Pengaruh Motivasi Usaha Terhadap Keberhasilan Usaha Dengan Kemampuan Usaha Sebagai Variabel Mediasi Pada Industri Kecil Menengah Makanan Ringan Priangan Timur-Indonesia." Jurnal Manajemen Teknologi $15 \quad$ (3): 297-323. https://doi.org/http://dx.doi.org/10.12695/jmt.2016.15.3.6.

Hadiyati, Ernani. 2012. "Kreativitas Dan Inovasi Pengaruhnya Terhadap Kewirausahaan Pada Usaha Kecil." Journal Inovasi Dan Kewirausahaan 1 (3): 135-51.

Hardian W. 2011. Karakteristik dan Perilaku Wirausaha Pedagang Martabak Manis Kaki Lima di Kota Bogor. [skripsi]. Bogor (ID): Institut Pertanian Bogor.

Josia Sanchaya Hendrawan, Hani Sirine. 2017. "Pengaruh Sikap Mandiri, Motivasi, Pengetahuan Kewirausahaan Terhadap Minat Berwirausaha (Studi Kasus Pada Mahasiswa Feb Uksw Konsentrasi Kewirausahaan).” AJIE - Asian Journal of Innovation and Entrepreneurship 02 (03): 291-314.

Mustikowati, Rita Indah, and Irma Tysari. 2014. "Orientasi Kewirausahaan, Inovasi, Dan Strategi Bisnis Untuk Meningkatkan Kinerja Perusahaan (Studi Pada Ukm Sentra Kabupaten Malang)." Jurnal Modernisasi 10 (1): 23-37. https://doi.org/10.21067/jem.v10i1.771.

Nazir M. 2011. Metode Penelitian, Cetakan Ke-7. Bogor (ID): Ghalia Indonesia. Soesarsono. 2002. Pengantar Kewirausahaan. Jurusan Teknologi Industri Pertanian Fakultas Teknologi Pertanian. Institut Pertanian Bogor. Bogor.

Purnama, Chamdan, and Suyanto. 2010. "Motivasi Dan Kemampuan Usaha Dalam Meningkatkan Keberhasilan Usaha Industri Kecil (Studi Pada Industri Kecil Sepatu Di Jawa Timur)." Jurnal Manajemen Dan Wirausaha 12 (2): 177-84. https://doi.org/10.9744/jmk.12.2.pp.177-184.

Syaukat, Yusman dan Sutara Hendrakusumaatmadja. 2004. Pengembangan Ekonomi Berbasis Lokal. Jurusan Ilmuilmu Sosial Ekonomi, Fakultas Pertanian, Institut Pertanian Bogor. Bogor.

Tadjudin.1997. Perkembangan Penduduk Sektor Informal. Yogyakarta: LESFI

Titus, Milan J. 1991. Regional and Rural Development Planning, Faculty of Geography UGM.

Tyson S, Jackson T. 2000. Perilaku Organisasi. Deddy Jacobus \& Dwi Prabantini, penerjemah. Yogyakarta (ID): ANDI. terjemahan dari: The Essence of Organizational Behaviour.

Yang, Xiushi. 1992. Temporary Migration and Its Frequency from Urban Households in China, Asia-Paciic population Journal, Vol.7 No.1, 1992, p. 27 - 50. 